\title{
THE BRAZILIAN MIDDLE CLASS AND THE ARCHETYPE OF CLASS PREJUDICE
}

\section{ORIGINAL ARTICLE}

GIESBRECHT, Daniel Florence ${ }^{1}$

GIESBRECHT, Daniel Florence. The Brazilian middle class and the archetype of class prejudice. Revista Científica Multidisciplinar Núcleo do Conhecimento. Year 05, Ed. 02, Vol. 04, pp. 104-124. February 2020. ISSN: 2448-0959, Access link in https://www.nucleodoconhecimento.com.br/history/archetype-of-prejudice

\section{SUMMARY}

This article aims to elaborate a historical reconstitution, from the long-term serial, the formation of the Brazilian middle class and also its archetype of class prejudice. We used as a starting point for our reflection the fact that Brazil lived more than three hundred years of slavery, which bequeathed the profusion of a racist imaginary, resulting in prejudiced practices and naturalized to afrodescendant populations, besides having extended to the poor citizen, in general. We try to relate in a historicist way the objects studied to the sociological concepts of socialization, besides characterizing the bourgeois ideas of the middle class and the Brazilian elites from the history of mentalities. We intend to contribute to a better understanding of the obstacles created by the lack of otherness practices in daily social relations.

Keywords: Social Class, prejudice, slavery, social exclusion, otherness.

\section{INTRODUCTION}

When we researched economic indicators about Brazilian potential, we noticed consistent and high numbers, very competitive compared to other countries, so much

${ }^{1} \mathrm{PhD}$ student in Contemporary History; Master in Education; Degree in Social Sciences, Degree in Pedagogy, Degree in History. 
so that Brazil, from the 1960s to today, is always among the fifteen countries with the highest gross domestic product in the world.

The numbers are not repeated if we seek reference data on poverty and inequality rates. Alarming realities of income distribution, high rates of violence, infant mortality, among others, are easily perceived in the eyes of those who travel through the vast Brazilian territory, giving the impression of being strolling through two completely different worlds: that of opulence and that of misery, an illusion of optics of an economy inserted successfully in the world scenario, but that masks a complex social reality , which presents, in its structure, marks of profound inequality.

We will use the word "poverty" to refer to the situation of millions of people living in Brazil. But the concept of poverty, depending on the context used and its semantic factoring, becomes complex and polysemic. It is from this semantic complexity that we propose to infer our reflection through this article, relating poverty to the archetype of the formation of the Brazilian middle class and its class interrelations.

In the intrinsic imaginary of the Brazilian middle class in its circles of socialization, the imagery of poverty is transfigured into a perception so simplified of the reality that surrounds them, to the point that the individual of the subaltern class, often in a state of insecurity, acquires unconsciously the discourse of the class to which it does not belong and by which it is exploited. In this situation, it is not difficult to come across everyday phrases of the purest common sense that seek, at all times, an explanation for the ills of the inequalities of the country: "He is poor because he is a vagabond", "Poor does not like to work" or, still, "Poor do not know how to do anything and can not learn anything".

Phrases like these end up producing a naturalization of the social, that is, it clings to the historical and social character of a fact reducing it to a natural event. Thus, something like lack ceases to be seen as a result of a structure assembled a priori, which ends up legitimizing inequalities in its praxis, to be considered a personal attribute of an individual. 
Taking as reference the idea of the naturalization of inequalities and individualization of expectations and failures ad hoc, it is necessary an accurate reflection of the class factors that contribute to the naturalization of the archetype of inferiorization of social groups at a disadvantage and that breaks the preconceived models since the advent of historical positivism of the nineteenth century that, transforming the social sciences into nature governed by immutable laws that escape human control, induce conformism, passive and resigned acceptance of what is historically and socially produced (Sucupira, 1984). The archetype of the poor who fail on a daily basis, so rooted in the Brazilian collective imaginary from the colony to contemporaneity, is in this sense an ideological operation, which serves to maintain a certain social order, that is, a configuration of economic life that benefits the social classes that produce this ideology.

We will first use Souza's theoretical framework (2019), which seemed more pertinent to the criticism of the paradigms that guide Brazilian social thought, especially that of "culturalism", in his attempts to explain the origins of inequalities in the country. It is also our intention to introduce to the reader the ideas that we will defend a posteriori, especially that the structuring of the mental archetype of the Brazilian middle class is one of the major obstacles to the construction of a country that consolidates republican values, and that creates conditions for the expansion of citizenship rights for millions of its inhabitants.

\section{POLISSEMIA OF POVERTY}

Poverty is a historical and social phenomenon. This means that it is closely related to the structure of society and the way each social class appropriates the goods produced or the wealth generated. It is not an easy concept, but we can use different criteria to try to define it.

The criterion of personal or family income has been the most used in Brazil, but we believe it is imprecise, due to many factors that have even worsened in recent years, such as the growth of informal activities, which prevents effective control of income[2]. 
In addition to income, another criterion used to configure poverty is to verify what is considered essential for the reproduction of life. This criterion, therefore, in our view, is also reductionist because, due to international conventions, it relates poverty only to food consumption.

It seems more pertinent to expand the concept to "basic needs", which would not be restricted only to food, but would include other aspects considered indispensable for the material reproduction of existence, expanding the idea of poverty for the inability of someone or a family to have means that allow access to a set of items considered essential for survival. This would also be configured if the person or family is excluded from the educational system, since schooling today is essential to enter the labor market. According to studies by Rocha (2006), it was only with the expansion of these concepts that we could understand a country of continental dimensions such as Brazil, immersed in enormous regional disparities.

Our argumentative idea is to exactly overcome the material view of the constitution of the concept of poverty for an abstract and unconscious psychological and structural valorization that, in the Brazilian historical construction, legitimizes this concept anchored in a methodological framework supported by the archetype of prejudice, which inferiorizes social groups constituted in a country that had, for more than three hundred years, the daily marks of an economy and society oriented at the expense of slave labor.

Prejudice can serve different material interests, which can be: class, gender, political, racial or ethnic and religious. But to demonstrate the constitution of prejudice naturalized by the Brazilian middle class, we undoubtedly need to know the historical structures that synthesized, through the pre-capitalist past, the distances between social groups of a society that, from the bipolarity between you and the slave, moved towards a more complex organization with the advent of commercial and industrial capitalism, but which has always maintained the archetype of the slave past.

Discrimination and prejudice can also produce feelings of resignation and conformity in the victims, who accept to be oppressed and exploited, as Sartre (1905-1980) 
warned in a play entitled The Respectful Prostitute[3] (1946). It seems to us the Brazilian case, with daily attitudes of its middle class of inferiorization of the less favored, causing them to introject their own prejudice and the idea of failure, believing that they are deserving of such discriminations.

\section{HISTORICAL ORIGINS OF PREJUDICE OF THE BRAZILIAN MIDDLE CLASS}

Between the 16th and 19th centuries, the African slave trade to America linked the two continents to what would become the most lucrative trade in Brazilian history. African slaves were present in the most diverse day-to-day activities. The naturalization of slavery has become something so rooted in the structures of society that it is very unlikely that it would be imagined without the traditional divisions of those who commanded and obeyed. This authoritarian model of social relations enables the understanding of the symbolic permanence practiced against the poorest populations, even after the abolition of slavery at the end of the 19th century.

With the development of Brazilian social thought, especially from the beginning of the 20th century, we have tried to explain the dichotomous picture experiencing by native society throughout its history. We believe that, for this task, the most appropriate theory, promoting a better understanding of the construction of this social structure, is that of serial history, present in fernand braudel's methodologie[4]s. Contemplating a semiotic analysis of the formation of Brazilian social classes is only possible when we perceive the serial of the long duration of slavery, which validated in the daily mentality of the country the archetype of prejudice, distancing and segregation, from casagrande to senzala, which, with the transition to modernity of the mercantile and industrial phase of capitalism, corroborated a new form of exploitation, but with the structural clothing of the old, segregating rich and poor within large cities, as well as in social circles.

It is also worth remembering that the development of classes in Brazil, according to Fausto (1997), is related to the consolidation of a proprietary class, which owns land ownership and other means of production. In a country that was once fundamentally 
agricultural, this class easily appropriated most of the wealth produced, since it exploited the enslaved labor.

Under the auspices of colonial society, it developed in a very particular way in the regions where the plantation system was consolidated, social relations outside the slavery between freedmen and owners. With the absence of a direct colonial system, in addition to a territorial immensity, which hindered the implementation of optimized forms of control under the tutelage of the Portuguese crown, and the creation of the system of distribution of hereditary captaincies - an attempt at public-private conciliation in the colonization process - ambiguous, contradictory and deregulated forms of relations between individuals of different classes were developed. It is in this scenario that we find the figure of the aggregate.

This intermediate stratum of formally free people, between masters and slaves, is formed by dependent men and women, both materially and symbolically of landowners and people. In the most economical and material sense, the dependence of this social extract is inexorable. (...) This constitutes among us - as an economic, political and social form the figure of the "aggregate". A fundamental figure in brazilian literature and historical sociology, the aggregate will form the first intermediate class between owners and dispossessed. (Sousa, 2018: 65-66).

Although still distant from the emergence of the modern Brazilian middle class, the group of households, even dependent and often thickening the statistics of the dispossessed population - the loss of the protection of their "godfather" was enough it is of paramount importance to understand the mental introjection of prejudice between the future social classes of modern Brazil, given that these, within a system of authoritarian domination of private power over the public, it was exactly the caste that naturalized the principles of control and violence practiced in a way, to some extent, sadistic by the slave-working ruralist elites, who also delegated to the aggregates the rights to oppress those seen as "instruments that spoke", bestialized and dehumanized. 
The fact that interests us from here is to realize that it was through this relationship of interdependence between lords and aggregates, in addition to the monopoly of force established below the state as organizer of society, that the feeling of contempt for the other was to lead to the constitution of sadistic behavior with the enslaved and the humblest. Pleasure from violence is commonly verified in the history of these intermediate classes in Brazilian society, to the point of being more intense - there we pe[5]rceive sadism as a form of group recognition, or superiority over the other - as an everyday practice of those we call free men. Scenes of humiliation, jokes, satires and obtuse behavior will be part of the scope of treatment perpetrated on the marginalized, which we will call social "scum".

Since the beginning of mining activity in the twilight of the seventeenth century and throughout the eighteenth century, Brazil experienced the phenomenon of urbanization, concentrated mainly in the captaincy of Minas Gerais. The stratified society of the Northeast sugar was the one of a more dynamic and multifaceted character in Vila Rica. Slavery and freedom went hand in hand in an interdependent economy, but it provided new forms of social ascension, including black liners ${ }^{[6]}$. The mining experience was peculiar, in which mestizo, blacks and Indians had a unique moment in which they could put into practice for the first time their talents, hence the large number of artists, craftsmen, accountants and the appearance of several other professions in the region. For the first time in the history of Brazil, a more expressive technical knowledge appeared to differentiate itself from a society built by "raw" and manual work, paving the way for the emergence of the modern middle class.

The early 19th century was the harbinger of new airs that would shake the European continent - and its biggest storm was Napoleon Bonaparte. The wars initiated by the French emperor were associated, in addition to his megalomaniacal ambitions, with the new form assumed by the capitalist system in its industrial stage. France, Britain's historical enemy, was starting a conflict of continental proportions to grab its fair share, in an omen of what would be the imperialist phenomenon still to be triggered in the middle of the century. This fact would have a direct and indirect impact on the future 
of Portugal and consequently brazil, because the metropolitan administrative structure would cross the seas to establish itself in the colony.

This process, which the portuguese royal family came to consolidate, was already foreseen in the discovery of mines, in the presence of some colonial cities of expression, in the need for greater vigilance over newly discovered wealth and greater control, from then on, on familismo and private mandonism. A symptomatic example of the passage of power from the countryside to the cities is the case of the debts of the previously uncollectable rural patriarchs, from then on being paid under police force. As important as the change from the economically dynamic center of the Northeast to the Southeast was the social transformation of large proportions, implying new habits, new social roles, new professions and, at the end of the day, the construction of a new social hierarchy. (Souza, 2019: 61).

Urbanization eventually represented a resizing of power structures, making it move from individual patriarchalism into the hands of the state that was organized. From a Weberian perspective, the legitimate monopoly of violence began to focus on the hands of state apparatus - such as the police, for example - merging with the prerogatives of the ancient forms of class authoritarianism, but maintaining the practice of sadism, previously privately, now perpetrated by public forces.

With the opening of the ports to friendly nations in 1808 , decreed by the then prince regent $\mathrm{D}$. João $\mathrm{VI}$, and with the signing of the trade and navigation treaties of 1810 , Brazil would experience transformations that would immediately impact its colonial structure. The environment of the port cities, mainly Rio de Janeiro, Salvador and Recife became, overnight, busy centers of commerce, with the entry of unknown products until then, which encouraged the formation of a monetary structure. Exchange and trade offices, import and export agencies, banks, in short, a multitude of activities hitherto unnecessary in the world of rural patriarchy, only experienced in their proper proportions in mining regions[7]. 
But the great social transformation brought about by this new Europeanized scenario of economic relations would be the entry of thousands of immigrants. In addition to the approximately 15,000 Portuguese who arrived together the royal family, English, German and French also came to Brazil, for reasons ranging from economic to artistic. The future country that would be born in 1822 already marked characteristics of an independent state.

Immigrants were free labor who, added to the free workers born in Brazil, would make up the modern middle class that we talked about earlier. A different class from the old rural household, occupying the intermediate portion of the social hierarchy, but without the need for the protection of its compadre. Liberal principles and individualism, which had been blowing since the 18th century with Enlightenment philosophy, entered the unconscious of the urban dweller. A kind of self made man of the tropics would populate the city's imaginary.

With mercantile capitalism opens a fundamental vacuum for its maintenance and reproduction: the need for cultural capital to operate it. Commercial, manufacturing, bureaucratic and teaching activities - to be in a few examples - require a form of technical and utilitarian knowledge for their operation, a fact that would contribute to the opposition of manual labor, hitherto commonly performed by the slave or the poorest. The middle class will be the group that will appropriate this knowledge and, through it, will distance itself from the humblest, those of heavy work, from the level of the beasts.

To the abandoned and forgotten, the disqualified tasks, typical of the rabble, remain. These, to a large extent, as in the case of domestic work, will be a continuation of slavery, now under new masks. The direct exploitation of muscle energy - which barely distinguishes us from a horse or mule - with little incorporated knowledge, is the distinctive, if not the only, characteristic in relation to workers with a higher degree of technical qualification. (Souza, 2018: 74). 
Both this new middle class, as well as the future minimally specialized working class, which we will call "low middle class", or "proletarian", will try at all costs to differentiate themselves from the population seen as "scum", formed mainly by blacks and halfbreeds. Since they do not have the means of production, they will at least try to imitate the symbolic values of elites, reflecting on the obsession with the Europeanization of customs and, through formal and technical education, in the distancing from manual labor, so depreciated by Western values. Here we have our first concrete manifestation of prejudice embedded by the modern middle class of the 19th century.

Endogenous and exogenous issues in relation to the Brazilian slave issue were determinant for the initial maturation of the process of modernization of labor relations and the maturation of industrial capitalism in the 19th century. Since Brazilian independence, England has been pressuring the newborn national state to demonstrate commitments to the gradual extinction of the slave trade practiced since the mid-16th century. Internal movements led by liberal intellectuals, such as the coffee elite itself, openly debated abolition.

Such facts, at first, could point out in a sui generis way that the country, at its pace, could be consolidating its transition from commercial to industrial capitalism, because the scenario that opened with the abolition of slavery would displace not only an enormity of capital to the productive sectors, but also the modernization of class relations, overcoming the amalgams of the obsolete slave system. But that's not what happened. Industrialization would only be consolidated in the following century, under the baton of the state, in the governments Getúlio Vargas and Juscelino Kubitschek, as well as in the dictatorial period. Overcoming slavery, in its symbolic field, would never be overcome.

Even with the abolition consummated in 1888, a fact that made Brazil the last country in the world to end formal slavery, the perverse scenario of physical and symbolic violence continued. In addition, freed blacks encountered enormous difficulties in their insertion in the labor market, as they still had to compete with the immigrant workforce, now deliberately stimulated as state practice. It was within this perverse relationship of permanence that, over time, brazil was formed, concomitantly with the urbanization 
process, a class of the population that was completely excluded from the basic principles of citizenship[8], and this would also affect its next generations, an effect that we will call the "cloudy snowball[9]".

\section{EXCLUDING INDUSTRIALIZATION AND THE BOURGEOIS IMAGINARY OF THE MIDDLE CLASS}

The old racial order did not disappear with the end of slave labor. Instead, it was assimilated and integrated into the new social structures arising from the development of free work. According to Fernandes (1974), the bourgeois revolution triggered with the end of slavery benefited only some segments of Brazilian society.

Among the most favored was the "white" portion of the population of European origin, corroborating the theories of bleaching in vogue in the country. This group benefited from all the transformations resulting from economic growth, the industrializing spurt, the urbanization process and the development of a city culture. The marginalized class, composed of Afrodescendants, remained on the margins of national society, excluded in much part from all the improvements that these transformations produced. These facts pointed out that the disarticulation of slave labor in the last decades of the 19th century was not accompanied by substantial changes in the old racial order, characterized by prejudice and discrimination. The social marginalization of about $50 \%$ of Brazilians clearly highlighted the limits of the country's economic modernization.

With the maintenance of the means of production in the hands of the agro-exportelite and the incipient industrial class, it was in the city and in its cosmopolitan environment that the bourgeois lifestyle was consolidated and, together with it, all its symbolism. It was with the emergence of the urban middle class, especially the one focused on intellectual and financial activities, that the sense of Europeanization and customs spread. The incorporation of European aristocratic values can be perceived in the adoption of a pattern of taste and luxury that sought to match that of the aristocratic layers. In a kind of "symbolic cannibalism", the more affluent middle class introjected prejudices and patriarchy, but with a clothing that was said to be modern. 
In a symbolic dialectic, the middle class is one of the best elements for us to perceive how the public and private sphere were fundamental to their self-affirmation, recognition and distinction. Even far from the modern concept of "meritocracy", one pe[10]rceives how the archetype of the most "well adapted" echoes in the imaginary of the average bourgeois. Merit replaced the birthright as a new form of social differentiation, as well as intellectual sophistication, another element that began to distinguish the middle class from the popular classes, still without access to free and quality public education.

The generalization of the middle class family, in which the woman took care of her children and household chores - controlling the work of numerous employees - and the man participated in the activities of the business world, is one of the striking aspects in this sense, because it gives the individual the feeling of continuity, seeing in his children the possibility of continuing with family business. Therefore, the incorporation of aristocratic values, more than mere fad, was part of the process of consolidating political and social hegemony and the middle class's worldview about society[11].

Once the bourgeois symbolic universe of the Brazilian middle class is established, it is clear the antagonistic perception of this one towards the other less affluent groups and their attempt to equip themselves symbolically with the elites, these rather truly holders of the means of production and real control of the country. This obsession to resemble elites will not be, except in some cases, recognized in the cash sphere, therefore, its symbolic equivalence by social status or [12]prestige remains, and this can be obtained or recognized through three elements: productive occupation (employment), consumption and lifestyle, all fully suited to modern capitalist society, or, more than that, one complementing the other.

With the conquest of status in the modern Brazilian meritocratic society, new forms of prestige become part of the new social hierarchy. The most important thing for the middle class, in addition to the "virtue" of imitation, is to distance oneanother from the daily practices of social "scum". Drinking wine to the detriment of cachaça, listening to classical music instead of popular music, attending theaters, literary academies and expensive restaurants for the exhibitionism of etiquette, in addition to international 
travel - with the right to advice from pseudointellectuals, feeding on the ambiguous feeling of revulsion at what is national - are small examples of this reductionist worldview.

\section{CULTURAL CAPITAL, SOCIAL INSTITUTIONS AND PREJUDICE}

Differently from the culturalist view identified at the beginning of our text as a way of explaining social inequalities and class relations, subjectivation concepts and justifying differences only from the individual material point of view, we need to start from the sociological understanding of primary and secondary institutions of socialization to understand the phenomenon of class hatred so present in everyday life.

In general, socialization begins in the family, an institution in which the individual learns the language and, through it, to communicate, to express needs, as well as feelings of discomfort or well-being. Psychological research such as piaget (2005) confirms the importance of parents and other family members in the formation of children's personality. These studies indicate that at the beginning of the socialization process family members tend to be more decisive than the individuals with whom the child comes into contact only occasionally. We find here a problem: in the organization of the Brazilian slave society everything was done to avoid the construction of bonds of solidarity between the enslaved populations, and the first institution fought was the family, compromising this stage of socialization. It is noteworthy that there was hardly room for the constitution of primary social bonds in prison, disregarding the psychic and emotional needs of captives.

The difficulty of family organization is not a mere phenomenon of the slave past, but remains, in due proportion, among the humblest populations, in the children, grandchildren and great-grandchildren of the former generations of demeaning. All this will have profound consequences in future secondary relationships, especially in school learning, causing less chance of prestige in the labor market. Weaker families are generally taxed as "misfit" by the upper classes, especially by the generalist discourse of the middle class, which, from the cradle, was able to build bonds of solidarity that will be determinant for future success. 
The current case of the exploitation of the Brazilian rabble to save time from dirty and heavy household chores - which allows you to use the "stolen" time at a vile price in more productive and well-paid activities shows a clear misery functionality such as sunlight. This silent class struggle exempts an entire class of childcare and home life, transforming time-saving money and qualifying learning. The stolen class, in this case, is condemned eternally to play the same secularly servile roles. (Souza, 2019: 85).

Save time on manual tasks and invest time in intellectual activities. As a result, greater professional training and, consequently, greater social prestige; a circle is established that has nothing to do with merit, or personal capacity, but rather with appropriation of greater cultural capital.

According to Bourdieu (2004), children from wealthy families tend to have higher school performance than young people from families belonging to the popular classes. In most cases, this is because students from the dominant classes have a cultural capital that others were unable to accumulate, not only in school, but also in the cultural formation of parents, who would teach their children the demands to maintain and expand their privileged social situation. Children in situations of social fragility do not have this protection network, tending to face much more difficulties because they do not have the knowledge and practices valued by the dominant culture. They would not participate in the values cultivated by these elites and, for this reason, would tend to consider school learning a form of violence against their social values and practices, explaining the high rates of dropout of the Brazilian schoo[13]ı.

At school, we may have the best practical perception of symbolic violence. In it, for example, it is common for students from popular classes to come across a language, a cultural practice and values that they do not know because they do not have a certain cultural heritage, or, as Bourdieu points out, a cultural capital that enables them to understand or assimilate them, compromising their school performance, becoming an impediment imposed by the institution itself and delegitimizing the performance of this student. Despite this, the student does not realize that his low school performance is 
determined by social factors and therefore often ends up inintroducing failure, compromising his self-esteem at a crucial moment in his not only academic but human training.

Having as point of reference the access and continuity in the formal education system as one of the main chances proclaimed by a society that considers itself "meritocratic", we find a subtle example of how the limitations imposed by the slave past are perpetuated, but almost invisible. If in the past we could perceive everything explicitly unequal, due to the phenotype and the explicit exclusion of slaves to institutions, today everything seems corrected due to the creation of a public education system, shifting all responsibilities of success or failure to the individual scope. It covers the sun with the si[14]eve, because most needy populations are excluded from cultural capital, deliberately appropriated by the middle class and elites, besides having access to an inefficient public service system.

In the capitalist world, the lack of material success condemns him to the status of failure. Imagine then being devoid of material capital and also cultural capital? Because the forms of class ascension in the predatory system of capital are not easy, the reproductive cycle of poverty and exclusion tends to perpetuate from birth to those who come from the poorest classes. This will result in the subject, in addition to less chances of constituting a formation that will enable him to compete with the children of the wealthy classes, much more likely to suffer all kinds of physical and symbolic violence.

As the reproduction of class inequality from the cradle is repressed both consciously and unconsciously, it is the stereotype of the black, easily recognizable, that easily identifies the enemy to be slaughtered and exploited. The "black danger" used as a password to massacre defenseless and quilombola for centuries is continued by other means in the open massacre, and today applauded without pejo, of poor and black in slums and prisons. And not only that. As there was no temporal continuity between slavery - which destroys the soul from within, humiliates and demeans the subject, making him an accomplice to his 
own domination - and the production of a rabble of misfits to the modern world, our excluded inherited, without a solution of continuity, all hatred and cowardly contempt for the weakest and with less capacity to defend themselves. (Souza, 2019: 88).

But why does such inequality not seem to be perceived by the Brazilian middle class? As we said at the beginning of this article, the theory of social classes taken by income criteria is insufficient to understand a complex social composition such as the Brazilian one, weakened by the consequences of its slave past. In our opinion it is necessary to overcome the mere economic bias to enter from the history of mentalities[15]. A middle-class citizen tends to think of it as his class, so he would have no instrumental basis for the perception of the other, making the exercise of otherness miserable or often unattainable. This absence of dialectics produces prejudiced people, devoid of perception of the other, in a country inserted in the 21st century within a competitive market order, which goes beyond the economic sphere, reaching the social, thought and perception of the world. Mental colonialism ends up dominating minds while maintaining the status quo.

\section{FINAL CONSIDERATIONS}

Tracing a historical reconstitution of the formation of the Brazilian middle class and its archetype of prejudice is not an easy task due to the ambiguity of the concept of social class itself. The factor that we believe is essential for this understanding is past slavery, which dramatically interferes in the understanding of the present and the Brazilian social fabric. It is only in the long-term serial that we can construct the narrative presented here and our argumentation for the understanding of classes from the sociocultural context, breaking with the traditional economicism of class theories, sometimes interpreted by liberal thinkers, sometimes by Marxist thinkers.

Identifying the importance of the slave past for the configuration of class mentalities perpetuated by social institutions, we can perceive the inequalities and socially constituted stereotypes that seem to reproduce ad infinitum. 
The family, the school, the organizations, all this promotes throughout our history the reproduction of the privileges of elitist groups and the middle class, which is camouflaged with the ink of pseudoscientific analyses of meritocracy, in one of the most unequal countries on the planet. The fallacy that it is possible the almost innate rise for some to the detriment of others was incorporated into the imaginary of the middle class so consistently that it managed to penetrate even the popular layers, in the phenomenon that we deal with in the text about the introjection of prejudice.

Being born in the middle class and upper middle class is almost synonymous with the reproduction of the success of past generations and the incorporation of privileges that will make a total difference in the future. They seem to be trivial facts, but acquiring from an early age the discipline of study, attending certain environments, living with people with the cultural capital necessary to excel in social relations, studying a foreign language in the school shift and being well fed are small examples of privileges that, added to hundreds of others, will shape the future successful citizen, as if his personal merit had been the great differential of such achievement.

Naturalizing daily violence against poor, black, women, among other minorities, is symptomatic of the violence that shaped Brazilian history. The echoes of slavery are heard in every death in the favela, in every aggression committed by the police, in every joke at sunday lunch told at the tables of families who have already naturalized racism as something morally acceptable, as if not demeaning human dignity, thus transforming the reality of the middle class into a cage of fears, anguish and systemic hatred.

\section{REFERENCES}

BONFIM, Paulo Ricardo. Educar, higienizar e regenerar: uma história da eugenia no Brasil. São Paulo: Paco, 2019.

BOURDIEU, Pierre. A economia das trocas simbólicas. São Paulo: Perspectiva, 2004.

BRAUDEL, Fernand. Escritos sobre a história. São Paulo: Perspectiva, 1978. 
CARVALHO, José Murilo de. Cidadania no Brasil: o longo caminho. São Paulo: Civilização Brasileira, 2003.

DOWBOR, Ladislau. A era do capital improdutivo. São Paulo: Editora Novas Palavras, 2017.

FAUSTO, Bóris. História do Brasil. 6. ed. São Paulo: Edusp/FDE, 1997. . História concisa do Brasil. São Paulo :Edusp, 2002.

FERNANDES, Florestan. Revolução burguesa no Brasil: ensaio de interpretação sociológica. Rio de Janeiro: Zahar, 1974.

FROMM, Erich. Anatomia da destrutividade humana. Rio de Janeiro: Zahar, 1975.

KENNETH, Maxwell. A devassa da devassa. São Paulo: Paz e Terra, 1995.

KLEIN, Naomi. Sem logo: a tirania das marcas em um planeta vendido. Rio de Janeiro: Record, 2002.

PARSONS, Talcott. Social structure \& person. USA: Free Press, 2007.

PIAGET, Jean. A representação do mundo na criança. Curitiba: Ideias e Letras, 2005.

ROCHA, Sônia. Pobreza no Brasil. Rio de Janeiro: FGV, 2006.

SARTRE, Jean Paul. A prostituta respeitosa. Campinas: Papirus, 1992.

SOUZA, Jessé. A classe média no espelho. Rio de Janeiro: Estação Brasil, 2018. A elite do atraso. Rio de Janeiro: Estação Brasil, 2019.

SUCUPIRA, Eduardo. Introdução ao pensamento dialético. São Paulo: Alfa-Omega, 1984.

VOVELLE, Michel. Ideologias e mentalidades. São Paulo: Brasiliense, 1987. 
WEBER, Max. A ética protestante e o espírito do capitalismo. São Paulo: Companhia das Letras, 2007.

YOUNG, Michael. The rise of meritocracy. United Kingdom: Transaction Pub, 1994

\section{APPENDIX A}

\begin{tabular}{|c|c|c|c|c|c|c|c|c|c|c|}
\hline \multirow{3}{*}{ Grandes Regiões e caracteristicas selecionadas } & \multicolumn{10}{|c|}{$\begin{array}{c}\text { Taxa de frequência liquida a estabelecimento de ensino da população residente de } 6 \text { a } 24 \text { anos de idade, por grupos de idade e nivel de } \\
\text { ensino (\%) }\end{array}$} \\
\hline & \multicolumn{2}{|c|}{$\begin{array}{l}6 \text { a } 14 \text { anos, no ensino } \\
\text { fundamental }\end{array}$} & \multicolumn{2}{|c|}{$\begin{array}{l}6 \text { a } 10 \text { anos, nos anos } \\
\text { iniciais do ensino } \\
\text { fundamental }\end{array}$} & \multicolumn{2}{|c|}{$\begin{array}{l}11 \text { a } 14 \text { anos, nos anos } \\
\text { finais do ensino } \\
\text { fundamental }\end{array}$} & \multicolumn{2}{|c|}{$\begin{array}{l}15 \text { a } 17 \text { anos, no ensino } \\
\text { médio }\end{array}$} & \multicolumn{2}{|c|}{$\begin{array}{l}18 \text { a } 24 \text { anos, no ensino } \\
\text { superior }\end{array}$} \\
\hline & Taxa & $\mathrm{CV}(\%)$ & Taxa & $\mathrm{CV}(\%)$ & Taxa & $\mathrm{CV}(\%)$ & Taxa & CV (\%) & Taxa & $\mathrm{CV}(\%)$ \\
\hline Brasil & 97,0 & 0,1 & 95,5 & 0,2 & 85,9 & 0,3 & 68,5 & 0,6 & 23,2 & 1,3 \\
\hline Norte & 96,6 & 0,2 & 95,0 & 0,4 & 79,4 & 1,0 & 59,7 & 1,8 & 17,7 & 3,3 \\
\hline Nordeste & 96,8 & 0,1 & 95,3 & 0,2 & 82,0 & 0,6 & 60,7 & 1,1 & 16,8 & 2,9 \\
\hline Sudeste & 97,3 & 0,2 & 95,7 & 0,3 & 89,2 & 0,5 & 76,5 & 1,0 & 25,8 & 2,4 \\
\hline Sul & 97,4 & 0,2 & 96,1 & 0,3 & 89,6 & 0,6 & 69,6 & 1,4 & 29,1 & 2,4 \\
\hline Centro-Oeste & 96,8 & 0,3 & 95,0 & 0,4 & 88,4 & 0,9 & 70,4 & 1,7 & 30,1 & 2,9 \\
\hline \multicolumn{11}{|l|}{ Situaçäo do dom icilio } \\
\hline Urbana & 97,1 & 0,1 & 95,5 & 0,2 & 87,2 & 0,3 & 70,6 & 0,7 & 25,6 & 1,4 \\
\hline Rural & 96,9 & 0,2 & 95,6 & 0,2 & 79,6 & 0,7 & 57,4 & 1,3 & 8,3 & 3,5 \\
\hline \multicolumn{11}{|l|}{ Sexo } \\
\hline Homem & 96,9 & 0,1 & 95,3 & 0,2 & 83,5 & 0,5 & 63,6 & 0,9 & 19,7 & 1,8 \\
\hline Mulher & 97,2 & 0,1 & 95,7 & 0,2 & 88,3 & 0,4 & 73,7 & 0,7 & 26,8 & 1,5 \\
\hline \multicolumn{11}{|l|}{ Cor ou raça (1) } \\
\hline Branca & 97,3 & 0,1 & 95,8 & 0,2 & 89,5 & 0,4 & 76,6 & 0,8 & 32,9 & 1,6 \\
\hline Preta ou parda & 96,9 & 0,1 & 95,3 & 0,2 & 83,7 & 0,4 & 63,5 & 0,9 & 16,7 & 1,8 \\
\hline \multicolumn{11}{|l|}{$\begin{array}{l}\text { Classes de percentual de pessoas em ordem } \\
\text { crescente de rendimento domiciliar per capita }\end{array}$} \\
\hline Até $20 \%$ & 96,6 & 0,2 & 94,9 & 0,2 & 78,9 & 0,6 & 54,7 & 1,3 & 6,6 & 4,5 \\
\hline Mais de $20 \%$ até $40 \%$ & 96,9 & 0,2 & 95,4 & 0,3 & 85,3 & 0,6 & 65,3 & 1,2 & 12,0 & 3,3 \\
\hline Mais de $40 \%$ até $60 \%$ & 97,5 & 0,2 & 96,1 & 0,3 & 90,1 & 0,6 & 73,9 & 1,0 & 20,1 & 2,6 \\
\hline Mais de $60 \%$ até $80 \%$ & 97,5 & 0,3 & 95,9 & 0,5 & 93,0 & 0,6 & 81,1 & 1,2 & 32,3 & 2,1 \\
\hline Mais de $80 \%$ & 97,8 & 0,3 & 96,1 & 0,5 & 95,0 & 0,5 & 90,7 & 0,8 & 58,3 & 1,5 \\
\hline
\end{tabular}

Fonte: IBGE Pesquisa Nacional por Amostra de Domicilios Continua, 2017, segundo trimestre.

Nota: (1) Não são apresentados resultados para amarelos, indigenas e pessoas sem declaração de cor ou raça

Disponível em: https://www.nucleodoconhecimento.com.br/history/archetype-of-prejudice 


\section{APPENDIX B}

\begin{tabular}{|c|c|c|c|c|c|c|c|c|c|c|c|c|}
\hline \multirow{4}{*}{$\begin{array}{l}\text { Grandes Regiöes e } \\
\text { Unidades da Fede raçäo }\end{array}$} & \multicolumn{12}{|c|}{ Distribuição percentual da população, por classes de percentual de pessoas em ordem crescente de rendimento real efetivo domic iliar per capita e cor ou raça (\%) } \\
\hline & \multicolumn{4}{|c|}{ Total } & \multicolumn{4}{|c|}{ Entre os $10 \%$ com menores rendimentos } & \multicolumn{4}{|c|}{ Entre os $10 \%$ com maiores rendimentos } \\
\hline & \multicolumn{2}{|c|}{ Branca } & \multicolumn{2}{|c|}{ Preta ou parda } & \multicolumn{2}{|c|}{ Branca } & \multicolumn{2}{|c|}{ Preta ou parda } & \multicolumn{2}{|c|}{ Branca } & \multicolumn{2}{|c|}{ Preta ou parda } \\
\hline & Percentual & CV (\%) & Percentual & CV (\%) & Percentual & CV (\%) & Percentual & CV (\%) & Percentual & CV $(\%)$ & Percentual & CV (\%) \\
\hline Brasil & 43,6 & 0,5 & 55,4 & 0,4 & 23,9 & 1,8 & 75,2 & 0,6 & 71,7 & 0,8 & 26,3 & 2,3 \\
\hline Norte & 20,1 & 1,9 & 78,4 & 0,5 & 12,5 & 6,8 & 84,8 & 1,3 & 34,2 & 3,8 & 64,4 & 1,9 \\
\hline Rondônia & 31,2 & 3,0 & 68,2 & 1,4 & 23,6 & 9,3 & 75,2 & 2,9 & 40,9 & 7,9 & 58,4 & 5,5 \\
\hline Acre & 19,1 & 4,3 & 79,9 & 1,1 & 14,1 & 12,5 & 85,3 & 2,1 & 31,8 & 8,2 & 67,7 & 3,8 \\
\hline Amazonas & 18,1 & 4,7 & 79,5 & 1,2 & 11,0 & 13,1 & 86,2 & 2,0 & 38,2 & 9,8 & 60,5 & 5,8 \\
\hline Roraima & 21,5 & 5,6 & 72,4 & 2,0 & 14,6 & 17,7 & 71,3 & 7,3 & 40,9 & 8,4 & 55,5 & 6,5 \\
\hline Pará & 18,2 & 3,3 & 80,6 & 0,8 & 11,8 & 12,6 & 85,8 & 2,2 & 30,0 & 5,5 & 68,9 & 2,4 \\
\hline Amapá & 19,3 & 6,5 & 80,3 & 1,6 & 10,6 & 26,6 & 87,7 & 3,6 & 25,9 & 13,4 & 73,4 & 4,8 \\
\hline Tocantins & 23,7 & 4,7 & 75,3 & 1,5 & 14,8 & 19,0 & 84,4 & 3,4 & 42,5 & 6,4 & 56,2 & 4,7 \\
\hline Nordeste & 24,8 & 1,2 & 74,6 & 0,4 & 18,7 & 3,3 & 80,8 & 0,8 & 42,8 & 2,7 & 56,4 & 2,0 \\
\hline Maranhão & 18,5 & 2,6 & 80,8 & 0,6 & 15,7 & 6,9 & 83,9 & 1,3 & 31,5 & 5,5 & 67,4 & 2,6 \\
\hline Paui & 20,5 & 4,8 & 79,4 & 1,2 & 18,6 & 11,0 & 81,2 & 2,5 & 40,9 & 7,6 & 58,6 & 5,5 \\
\hline Ceará & 27,5 & 2,2 & 71,9 & 0,8 & 20,4 & 6,2 & 79,1 & 1,6 & 46,9 & 4,3 & 52,6 & 3,8 \\
\hline Rio Grande do Norte & 36,7 & 2,6 & 63,1 & 1,5 & 30,6 & 7,1 & 69,1 & 3,1 & 50,9 & 5,5 & 48,8 & 5,8 \\
\hline Paraba & 33,8 & 3,0 & 66,1 & 1,5 & 30,1 & 7,2 & 69,8 & 3,1 & 54,1 & 5,4 & 45,7 & 6,3 \\
\hline Pernambuco & 30,7 & 3,0 & 68,5 & 1,4 & 23,2 & 8,3 & 76,5 & 2,5 & 51,5 & 5,8 & 47,4 & 6,2 \\
\hline Alagoas & 23,4 & 2,8 & 76,1 & 0,9 & 21,8 & 6,3 & 77,9 & 1,8 & 36,1 & 6,6 & 63,5 & 3,8 \\
\hline Sergipe & 20,8 & 5,4 & 78,3 & 1,4 & 13,6 & 13,9 & 85,7 & 2,2 & 36,6 & 12,4 & 61,7 & 7,3 \\
\hline Bahia & 19,2 & 3,9 & 80,2 & 0,9 & 14,7 & 9,4 & 84,6 & 1,6 & 35,3 & 9,1 & 63,6 & 4,9 \\
\hline Sudeste & 51,2 & 0,9 & 47,6 & 1,0 & 35,2 & 2,8 & 64,2 & 1,5 & 78,1 & 1,1 & 19,0 & 4,6 \\
\hline Minas Gerais & 40,4 & 1,7 & 59,3 & 1,2 & 24,5 & 5,5 & 75,2 & 1,8 & 64,8 & 2,6 & 34,8 & 4,8 \\
\hline Espírito Santo & 39,2 & 2,6 & 60,2 & 1,7 & 22,5 & 10,6 & 77,2 & 3,1 & 64,5 & 3,0 & 35,2 & 5,6 \\
\hline Rio de Janeiro & 43,8 & 1,7 & 55,7 & 1,3 & 28,4 & 5,2 & 71,2 & 2,1 & 74,5 & 1,9 & 24,8 & 5,8 \\
\hline São Paulo & 60,1 & 1,2 & 38,1 & 2,0 & 46,8 & 3,7 & 52,4 & 3,3 & 83,1 & 1,4 & 12,3 & 9,0 \\
\hline sul & 75,6 & 0,5 & 23,7 & 1,7 & 59,3 & 2,1 & 39,9 & 3,2 & 91,3 & 0,6 & 7,9 & 6,9 \\
\hline Paraná & 67,2 & 1,1 & 31,7 & 2,3 & 52,2 & 3,8 & 46,7 & 4,3 & 86,7 & 1,3 & 11,4 & 9,4 \\
\hline Santa Catarina & 82,8 & 0,7 & 16,9 & 3,4 & 68,5 & 2,9 & 31,2 & 6,4 & 92,8 & 0,9 & 6,8 & 11,7 \\
\hline Rio Grande do Sul & 79,6 & 0,9 & 20,0 & 3,5 & 64,2 & 3,3 & 35,2 & 6,1 & 94,4 & 0,9 & 5,5 & 15,4 \\
\hline Centro-Oeste & 36,3 & 1,4 & 62,6 & 0,8 & 25,0 & 4,5 & 74,0 & 1,5 & 56,2 & 3,4 & 41,0 & 4,0 \\
\hline Mato Grosso do Sul & 43,2 & 2,6 & 55,5 & 2,1 & 28,9 & 8,7 & 69,1 & 3,7 & 65,0 & 3,6 & 34,1 & 6,8 \\
\hline Mato Grosso & 31,8 & 3,2 & 67,0 & 1,5 & 23,7 & 12,3 & 74,9 & 3,9 & 54,4 & 4,8 & 43,9 & 6,0 \\
\hline Goiás & 35,7 & 2,2 & 63,6 & 1,2 & 23,9 & 7,4 & 75,8 & 2,3 & 51,6 & 4,2 & 47,7 & 4,6 \\
\hline Distrito Federal & 36,7 & 4,1 & 61,6 & 2,4 & 22,8 & 11,0 & 76,5 & 3,3 & 59,3 & 10,5 & 29,1 & 10,0 \\
\hline
\end{tabular}

\section{APPENDIX C - FOOTNOTE REFERENCES}

2. Para o entendimento da financeirização do capitalismo e suas repercussões no mundo do trabalho, vide DOWBOR, Ladislau. A era do capital improdutivo. São Paulo: Editora Novas Palavras, 2017.

3. SARTRE, Jean Paul. A prostituta respeitosa. Campinas: Papirus, 1992. In this piece, the author portrays how the introjection of prejudice, incorporated by the victim, is naturalized within the society of the southern United States.

4. BRAUDEL, Fernand. Escritos sobre a história. São Paulo: Perspectiva, 1978.

5. FROMM, Erich. Anatomia da destrutividade humana. Rio de Janeiro: Zahar, 1975. 
6. Uma das obras mais consistentes e rica em fontes primárias sobre a organização das regiões mineradoras é de KENNETH, Maxwell. The debauchery of the debauchery. São Paulo: Paz e Terra, 1995.

7. Sobre o período em questão, vide FAUSTO, Bóris. História concisa do Brasil. São Paulo: Edusp, 2002.

8. Para um melhor entendimento sobre a construção do processo da cidadania brasileira, vide CARVALHO, José Murilo de. Cidadania no Brasil: o longo caminho. São Paulo: Civilização Brasileira, 2003.

9. We metaphorically used the expression "cloudy snowball", because blacks, mestizo, indigenous, brown, besides of course the marginalized white population, thickened the contingent of segregated "slag" from brazilian hierarchical society. During the 19th century, Scientific Racism and the principles of eugenics found in America, particularly in American eugenicists, its main spokespersons. Although prejudice in Brazil is erroneously restricted to phenotypic issues, the role played by eugenicists in stimulating bleaching policies, deliberately assumed by the Brazilian government in order to purify the genetics of the population, is considerable. This contributed directly to the stimulus to racism and animalization of individuals considered "inferior". BONFIM, Paulo Ricardo. Educar, higienizar e regenerar: uma história da eugenia no Brasil. São Paulo: Paco, 2019.

10. In Brazil, the concept of "meritocracy" permeates common sense and demagoguery. In our view, it is only understood "meritocracy" if we enter its origin in the literature in which the concept is born in a satirical and ironic way. Ver YOUNG, Michael. The rise of meritocracy. United Kingdom: Transaction Pub, 1994.

11. "With the advent of mass culture in the twentieth century, capitalism creates a new symbolism of false inclusion, introducing into contemporary society what we call the "suppression of subjectivity", raising the development of the so-called "mimetic behavior", that is, the individual would have stopped developing a personality of his own, original, that would put him in conflict and tension with the established social 
reality." KLEIN, Naomi (2009). Sem logo: a tirania das marcas em um planeta vendido. Rio de Janeiro: Record, 2002.

12. Tomamos como referência o conceito de status em WEBER, Max. Protestant ethics and the spirit of capitalism. São Paulo: Companhia das Letras, 2007.

13. According to Appendices $A$ and $B$, we can clearly note the historical ills of the process of exclusion of black and brown populations in their educational path, distancing these groups from the mechanisms of access required by contemporary society for a dignified life, which demands a better professional placement, compromising their incomes and their capacity to enter the capitalist world.

14. Brazilian popular expression used to describe ineffective measures for certain problems.

15. VOVELLE, Michel. Ideologias e mentalidades. São Paulo: Brasiliense, 1987.

Sent: December, 2019.

Approved: February, 2020. 